Павлишин Л. Г., доктор фбілособбських наук, профессор кафедри фбілософбї та суспільних наук Тернопільського національного педагогічного університету імені Володимира Гнатюка

\title{
ПРОБЛЕМА МОРАЛІ У ФІЛОСОФСЬКИХ ПОГЛЯДАХ I. КАНТА ТА Г. ГЕГЕЛЯ
}

\begin{abstract}
Анотація. У статті зосереджено увагу на думках I. Канта та Г. Гегеля, представників німецької класичної філософії щодо проблеми моралі, свободи у здійсненні того чи іншого вчинку. За Кантом, всі моральні вчинки грунтуються на категоричному імперативі. Людина як суб'єкт морального ставлення є автономною, а тому іiі моральні вчинки залежать від неї. Моральний закон - це вимога виконувати обов'язок як акт доброї волі, вільної від будь-яких чуттєвих або розсудкових мотивів. Мета задовольняє прагнення розуму виходити за межі досвіду. Необхідно відчути свою єдність з іншими стосовно мети, працювати для іiї досягнення, відчуваючи при цьому обов'язок та свій зв'язок із вищим світовим порядком. Кант вважав, що релігія повинна грунтуватися на моралі. Віра допомагає примирити вимоги моральної свідомості з фактами зла, які панують у людському житті.

За Гегелем, моральною може бути лише справжня совість. Моральний суб'єкт повинен володіти свободою совісті, тобто сприяти збільшенню і поширенню добра у суспільстві. Силу законів практичного розуму можна перевірити під час зіткнення з аморальними вчинками. Показником моральної сутності людини є не іiі наміри, а моральні справи. Людина стане володарем свободи тоді, коли буде володарем самої себе. Найвищий моральний обов'язок кожної людини полягає у повазі до держави як до божественної істоти. Найкращою державною формою Гегель вважав конституційну монархію.

Завдяки діалектичному методу та історичному чуттю Гегель зумів розкрити численні грані моралі, на які не надто звертали увагу його попередники. Моральність $\epsilon$ вищою стадією розвитку об'єктивного духу, істиною, сутністю права і моралі. Моральність постає як діалектична єдність всезагальної й одиничної волі, де всезагальна воля виступає сутністю одиничної. У моральності здійснюється всезагальне взаємовизнання свободи всіх людей у суспільстві. Трьома формами розвитку моральності Гегель вважав сім'ю, громадянське суспільство та державу. Сім'я - це необхідне соціальне єднання подружжя та їх дітей, яке засноване на природному почутті взаємної любові та довіри.
\end{abstract}

Ключові слова: мораль, свобода, обов'язок, категоричний імператив, вчинок, воля, суспільство.

Постановка проблеми. Принципи раціоналізму, що домінували у XVII-XVIII ст., знайшли своє відображення у філософiї I. Канта, Й. Фіхте, Ф. Шеллінга, Г. Гегеля, хоча звичайно ж були переосмислені ними. Варто наголосити на тому, що вони зберегли у своїх філософських поглядах просвітницьку віру у людину, наділену розумом. Критикуючи погляди німецьких просвітників, І. Кант не погоджувався 3 теорією «розумного егоїзу», в основі якого лежить прагнення до самозбереження, заперечував роль інтересу в моральності людини, вплив навколишнього середовища на іiі дії. Кант відкидав натуралістичну етику, яка вважала, що моральність грунтується на природі людини або соціальному прагматизмі. Кант вважав, що людина зазвичай не може дотримуватися морального обов' язку, проте переборює себе і діє згідно з ним. Розум немовби диктує волі людини моральний закон у формі обов'язкової вимоги або ж категоричного імперативу. Категоричним він $€$ тому, що його потрібно дотримуватися не заради певних цілей, а задля нього самого. Кант запропонував такі формулювання категоричного імперативу: «чини так, щоб ти завжди ставився до людства і у своїй особі, і в особі будь-кого іншого як до мети і ніколи як до засобу»; «чини так, щоб максима твоєї волі могла мати також і силу всезагального закону». Сформулювавши раціональні основи моралі, категоричний імператив, описавши мотиви моральних вчинків (повага до закону, почуття обов'язку), Кант все-таки вважав, що доброчесності у світі немає, оскільки люди егоїстичні істоти, які прагнуть земних задоволень та щастя. Проте людина як суб' єкт морального відношення $€$ автономною, а тому іiі моральне рішення залежить від неї. Самопізнання допомагає людині мати добру волю, засновану на розумі. Це дає їй змогу перебороти егоїстичну, злу волю. Людині варто заглибитися в себе, щоб почути голос, що звучить із глибини іiі серця. У процесі свого саморозвитку, стверджував Г. Гегель, людина повинна вийти за межі природної волі та перейти до другої стадії розвитку свободи волі свавілля. На цій стадії воля постає здатністю окремої людини вільно обирати із багатьох зовнішніх обставин, бажань, намірів одну обставину чи бажання.

Аналіз останніх досліджень і публікацій. Низка вітчизняних науковців, серед яких Є. Бистрицький, А. Єрмоленко, Г. Заїченко, П. Гнатенко, В. Окороков, Ю. Кушаков, М. Мінаков, В. Табачковський, займалися зазначеною проблематикою у поглядах І. Канта. Його філософія поставала предметом уваги й російських авторів, зокрема, Р. Бурханова, В. Жучкова, В. Кузнєцова, Н. Мотрошилової, Т. Ойзермана.

Глибокий аналіз думок Г. Георгапостав упрацях К. Бакрадзе, Б. Биховського, О. Богомолова, А. Гулиги, Е. Ільєнкова, Н. Мотрошилової, І. Нарського, М. Овсяннікова, В. Соколова. Вагомий внесок у вивчення філософії Г. Гегеля здійснили праці представників київської філософської школи (В. Шинкарука, В. Табачковського, І. Бичка, М. Булатова, А. Лоя, М. Поповича).

Метою статті $є$ з'ясування та аналіз поглядів Канта та Гегеля щодо проблеми моралі, iї раціонально-емоційних основ, iї ролі у становленні людини як інтелектуальної істоти.

Виклад основного матеріалу дослідження. Моральне, стверджував I. Кант, не властиве людині від природи, однак 
вона може його досягнути. Оскільки мораль має апріорне походження, то їі, на думку Канта, неможливо вивести із сущого, 3 фактів. Мораль тотожна законодавчому практичному розуму. Всезагальний закон практичного розуму - це і є моральний закон, який тотожний свободі, за Кантом. Свобода полягає у тому, що людина у своїх вчинках керується законом, який знаходить у собі. 3 цього приводу доречними будуть слова, що «той, хто хоче бути вільним, прагне усунути перешкоди; боротися за особисту свободу означає прагнути покласти край втручанню, експлуатації, поневоленню з боку людей, чиї цілі відрізняються від твоїх» [1, с. 52]. Оскільки моральний закон як вияв абсолютної волі до добра виникає у всіх людей, то він набуває характеру всезагального закону. За Кантом, людина більше схильна до зла, ніж до добра. Така позиція філософа грунтувалася на його твердженні про те, що є суперечність між абсолютним волінням до добра, яке апріорно властиве людській свідомості, і її чуттєво-розсудковою діяльністю. На думку Канта, причина такої суперечності полягає у зв'язку з недосконалістю людської свідомості. Подолати цю суперечність можна шляхом виконання категоричного імперативу. Мораль одна для всіх у всі часи і за будь-яких обставин. Кант пояснював, що мораль $€$ вченням не про те, як ми повинні зробити себе щасливими, а про те, як ми повинні стати гідними щастя. Щасливий не той, хто насолоджується тим, що він здійснив свої мрії, а той, хто задоволений своєю поведінкою.

Великого значення у становленні людини як особистості та громадянина Кант надавав обов'язку, який завжди повинен контролювати вчинки людини. Заперечуючи заохочення моральних вчинків, Кант стверджував, що усвідомлення виконаного обов'язку є єдиною нагородою. Моральний обов'язок не передбачає задоволення чи певних позитивних наслідків (авторитет, слава, честь) для людини, яка допомагає іншим. За Кантом, людина повинна бути щасливою, оскільки цього вимагає обов'язок. Філософ розмежовував моральний обов'язок та любов до ближнього, симпатію, радість від спілкування 3 іншими людьми, без чого наше життя неможливе. Кант вважав, що заповідь «любіть ближніх своїх, як самих себе» не постає як чистий етичний закон, тому що вона може виконуватися не лише 3 почуття обов'язку, а й зі схильності. Так, наприклад, за Гегелем, мораль - це суб'єктивні переконання людини, мотиви ії поведінки, їі цілі та наміри.

Кант поділяє точку зору просвітників стосовно того, що немає ніякої іншої істини, окрім істини розуму. Що міцнішою стає віра в те, що справжнім багатством розуму є усе те, що здобув він сам, то більше людський розум досягає свого морального призначення, яке складає зміст його пізнавального життя. Так, наприклад, П.-А. Гольбах стверджував, що людина позбавлена свободи, іiі доля залежить від низки причин, а тому потрібно підкорятися необхідності, бо «...вчення про необхідність не лише $є$ істинним і грунтується на надійному досвіді, але дає, крім того, стійку, непохитну основу моралі» [2, с. 251]. Він вважав, що людина, яка усвідомила неминучість необхідності, ніколи не буде рабом.

Просвітники 3 математичної точки зору підходили до аналізу людини, вбачаючи іï сутність у природних потребах, прагненні до щастя. Натуралізм вони поєднували з великими сподіваннями на силу розуму, який, еволюціонуючи, відіграє суттєве значення у житті людини, визначає характер іiї вчинків, поведінку. Така позиція щодо пізнання людини була причиною того, що вона поставала, з одного боку, як ланка у всесвітньому ланцюгу причинно-наслідкових зв'язків, а з іншого боку, вона, наділена розумом, - вершина природи. Отже, людина як істота, що наділена розумом, завдяки йому може претендувати на свободу. За Ж.-Ж. Руссо, людина, відчуваючи в собі двояку натуру, намагається повернутися до природи, бо повернення до природного стану людей забезпечило б їм свободу. На його думку, «відмовитися від своєї свободи - це значить відмовитися від своєї людської гідності...» [3, с. 203].

Коли Кант говорив, що його століття є століттям Просвітництва, то це можна трактувати як те, що за допомогою своєї філософії він надав часові, в якому жив, статусу просвітництва. «Просвітництво є виходом із стану свого неповноліття, в якому воно знаходиться через власну провину, нездатність користуватися своїм розумом» [4, с. 27]. Тому людина повинна знайти в собі мужність користуватися власним розумом. На думку Канта, це є девіз Просвітництва. Людині важко вийти зі стану неповноліття, який став для неї таким звичним та природним, а інколи навіть приємним. Тому дуже важко на перших порах користуватися власним розумом, адже це так незвично, тому що тривалий час людина цього не робила. Просвітництво потребує свободи, яку можна здобути хіба що за допомогою революції. Людині необхідна свобода, яка передбачає використання власного розуму. Суспільству, на думку Канта, ще дуже багато не вистачає для того, щоб люди могли користуватися розумом, але вже $є$ ознаки того, що це невдовзі буде можливо. Лише освічена людина «не боїться власної тіні», бо вона «є чимось більшим, ніж машина, відповідно до їі гідності» [4, с. 34-35].

Висновки. У моральності здійснюється всезагальне взаємовизнання свободи всіх людей у суспільстві. Діалектичною взаємодією у його етичних поглядах пронизані всі моральні категорії етики - «умисел» і «провина», «намір» і «благо», «добро» і «совість». Гегель вважав, що добро - це реалізована свобода. Воно постає як сутність особливої волі суб' Єкта, поза ним суб'єктивна воля позбавлена морального змісту та мети. Добро - це все те, що сприяє збереженню життя та щастю людини. Кожна мисляча людина прагне пізнати добро, робити його своїм наміром та реалізовувати на практиці, бо інакше воно залишиться лише абстракцією. Досконале пізнання добра та вміння визначати його мисленням Гегель назвав совістю. Справжня совість, на думку Гегеля, полягає в абсолютній переконаності мислячої особистості в тому, що вона правильно пізнала добро, чітко його дотримується у своїх намірах та використовує у діяльності. Він виокремив справжню і формальну совість. Перша відповідає суспільному етосу, який є їі сутністю, а друга - індивідуальна, а тому може суперечити суспільній моральності. Моральною може бути лише справжня совість.

Як і Руссо, Кант вів мову про етику почуття, хоча й вніс власне бачення у розв'язання цієї проблеми. Кант вибудував етику, що грунтувалася на принципах орієнтації на належне, раціоналізму, онтологічної двоїстості людини, апріоризму, антинатуралізму й автономності (незалежність моральних постулатів від позаморальних підстав і доведень). На думку Канта, людина залучається до свободи як ноуменальна істота, а у феноменальній сфері вона змушена змиритися iз суворою детермінацією. Наголошуючи на суперечності між необхідністю і свободою, Кант вважав, що ця суперечність не $€$ цілком виправданою, оскільки людина чинить 3 необхідністю в одному випадку і вільно - в іншому. 3 одного боку, людина діє 
під впливом детермінізму, з необхідністю, бо вона, істота, що наділена думками, почуттями, бажаннями, є «явищем» серед інших «явищ» природи. 3 іншого боку, людина - моральна особистість, що належить до умоглядного світу «речей у собі», і у цьому випадку вона - вільна. На думку ж Гегеля, моральний суб'єкт повинен володіти свободою совісті, тобто сприяти поширенню добра у суспільстві.

\section{Лimepamypa:}

1. Берлін І. Чотири есе про свободу / І. Берлін; пер. з англ. О. Коваленка. Київ : Основи, 1994. 272 с.

2. Гольбах П. А. Избранные произведения : в 2 т. Т. 1. Москва : Изд-во соц.-эконом. лит., 1963.715 с.

3. Руссо Ж.-Ж. Об общественном договоре. Трактаты / Ж.-Ж. Руссо. Москва : Канон-Пресс-Ц «Кучково Поле», 1998. 414 с.

4. Кант И. Сочинения: в 6 т. / Кант И. ; под общ. ред. В. Ф. Асмуса и др. Москва : Мысль. Т. 6. 1966. 743 с.

Pavlyshyn L. The problem of morality in the philosophical views of I. Kant and G. Hegel

Summary. The article focuses on the opinions of I. Kant and G. Hegel, representatitives of German classical philosophy, about the problem of morality, freedom in the implementation of a particular act. As for Kant all moral acts always are based on the categorical imperative. Man as the subject of moral attitude is autonomous and his moral actions depend on him.
The goal satisfies the desire of reason to go beyond experience. It is necessary to feel unity with others about purpose, try to achieve it, to feel the responsibility and connection with a higher world order. Kant believed that religion have to be based on morality. Faith helps reconcile the demands of moral consciousness with facts of evil that prevail in human life.

According to Hegel, only true conscience can be moral. The moral subject must own freedom of conscience, increase and spread the good in society. The indicator of our moral essence is our moral affairs but not intentions. A man will be the owner of freedom if he will be the owner of himself. Every ma's highest moral duty is to respect the state as a divine being. The best state form is a constitutional monarchy. Thanks to the dialectic method and the historical plague, Hegel managed to reveal the numerous facets of morality, which were not too much drawn to its predecessors. Morality is the highest stage in the development of objective spirit, truth, essence of law. Morality appears as a dialectical unity of all-general and individual will where all-general will is the essence of a single will. Morality carries out all-general mutual knowledge of freedom of all people in society. Hegel pointed out three forms of development of morality such as family, civil society and state. The family is a necessary social union of the spouses and their children and based on the natural feeling of mutual love and trust.

Key words: morality, freedom, duty, categorical imperative, act, will, society. 